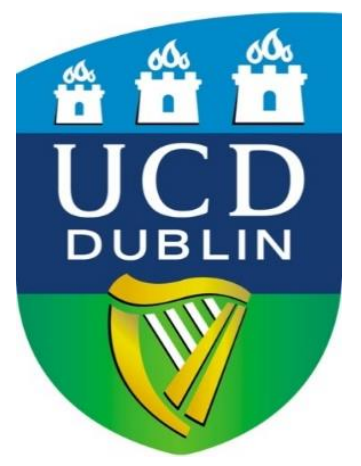

UCD GEARY INSTITUTE FOR PUBLIC POLICY

DISCUSSION PAPER SERIES

\title{
Subordinate Resolution - An Empirical Analysis of European Union Subsidiary Banks
}

\author{
Thomas Conlon, \\ Smurfit Graduate Business School, \\ University College Dublin \\ John Cotter, \\ Smurfit Graduate Business School and Geary Institute for Public Policy, \\ University College Dublin
}

Geary WP2015/01

Feb 5, 2015

(Updated May 22, 2019)

UCD Geary Institute Discussion Papers often represent preliminary work and are circulated to encourage discussion. Citation of such a paper should account for its provisional character. A revised version may be available directly from the author.

Any opinions expressed here are those of the author(s) and not those of UCD Geary Institute. Research published in this series may include views on policy, but the institute itself takes no institutional policy positions. 


\title{
Subordinate Resolution - An Empirical Analysis of European Union Subsidiary Banks
}

\author{
Thomas Conlon ${ }^{\mathrm{a}, *}$, John Cotter $^{\mathrm{a}}$ \\ ${ }^{a}$ Smurfit Graduate School of Business, University College Dublin, Carysfort Avenue, \\ Blackrock, Co. Dublin, Ireland.
}

\begin{abstract}
To help curtail future sovereign exposures to banking losses, the European Union introduced the Bank Resolution and Recovery Directive, which mandates bail-in of creditors in the event of significant bank losses. In this paper, we examine the impact of resolution on subsidiary banks, notable in terms of their substantial role throughout the European Union. Significant differences in risk and funding characteristics are apparent between domestic and cross-border European bank subsidiaries. Subsidiary banks are found to possess a larger proportion of loss absorbing capacity than underlying parent banks. Results indicate the suitability of single point of entry resolution in the case of domestic subsidiaries and multiple points of entry resolution for cross-border subsidiaries. Our findings highlight a worrying decline in loss absorbing capacity in European banks more generally since 2006, pointing to a necessary future focus on broad capital thresholds to ensure the success of the resolution model.
\end{abstract}

Keywords: Resolution Planning; Bail-In; Bank Failure; Bank Subsidiaries

${ }^{*}$ Corresponding Author, Tel: +353-1-716 8909.

Email addresses: conlon.thomas@ucd.ie (Thomas Conlon),john.cotter@ucd.ie (John Cotter)

The authors are grateful for the support of the Banking and Payments Research Programme, developed by The Institute of Banking and Banking \& Payments Federation Ireland. This publication has emanated from research conducted with the financial support of Science Foundation Ireland under Grant Number 16/SPP/3347 and 13/RC/2106 and 17/SP/5447. 


\section{Introduction}

The global financial crisis and subsequent European sovereign debt crisis have again highlighted the fragility of the global banking sector. ${ }^{1}$ Policy makers have responded by mandating that banks hold greater quantities of high quality capital and by placing the burden of losses upon creditors. The latter proposal, popularly referred to as 'bail-in', is an attempt to break the implicit link between banking losses and sovereign rescues of financial institutions. To this end, the European Union introduced the Bank Resolution and Recovery Directive (BRRD) with the objective of providing a consistent set of rules surrounding bank resolution in the 28 countries of the European Union (The European Commission, 2012). One of the primary obstacles to practical implementation of bank resolution plans is the question of how to treat cross-border subsidiaries ${ }^{2}$, especially common within the Eurozone. Total assets of EU parent banks amounted to $€ 34.2$ trillion in 2014, with the largest 10 banks accounting for 48.5\%. Assets of domestic subsidiaries were $€ 6.97$ trillion, while cross-border subsidiary assets were $€ 4.09$ trillion, highlighting the central importance of subsidiary banks. In this paper, we provide a taxonomy of risk and funding characteristics of European banking subsidiaries in the context of bank resolution planning.

The banking crisis which emerged from 2008 onwards resulted in a changed landscape for banking regulation and supervision. For member states of the EU, the BRRD is applicable to all incorporated credit institutions ${ }^{3}$ (Huertas, 2016). Within the Eurozone, the BRRD is being implemented under the Single Resolution Mechanism

\footnotetext{
${ }^{1}$ Goddard et al. (2009) outline the events of the global financial crisis on European banks. Trichet (2010) describes the response to the financial crisis from the European Central Bank.

${ }^{2}$ In this study, we define 'parent banks' as the ultimate owner at the highest corporate level possible, often a bank holding company. 'Domestic subsidiaries' are specified as banks where the primary business operations are in the same jurisdiction as the parent, but where a separate legal entity has an obligation to provide accounting and regulatory reporting. 'Cross-border subsidiaries' are similarly defined, but the subsidiary must be located in a different sovereign jurisdiction than the parent.

3 A credit institution is defined as undertaking the business of taking deposits or other repayable funds from the public and granting credits for its own account. Given the overlap with the distinguishing characteristics of banks as a financial intermediary that offers loans and deposits, and payment services (Casu et. al. 2015) and the filters employed to remove non-commercial bank entities, described in Section 2, we adopt the generic term subsidiary 'banks' throughout this study.
} 
$(\mathrm{SRM})^{4}$, with similar frameworks introduced in other non-Eurozone countries. ${ }^{5}$ The BRRD mandates bail-in of investors in the event of banking losses, which corresponds to mandatory writedown of liabilities or their conversion to equity for recapitalization purposes. Bail-in will apply to any bank liability not backed by assets or collateral and will be applied in order of capital structure hierarchy. ${ }^{6}$

Two primary resolution options are available to regulators to deal with banks havnig cross-border operations (Karamichailidou and Mayes, 2016). The first, single point of entry (SPOE), involves the resolution of a banking group at the parent or ultimate owner level by a single resolution authority. The second, multiple points of entry (MPOE), involves resolution of parts of a banking group as separate entities in different jurisdictions by multiple regulators. The appeal of SPOE resolution is relative simplicity but implementation may be hampered by asymmetric losses across multiple jurisdictions (Bolton and Oehmke, 2016). The SPOE approach may also be vulnerable to legal impediments, especially in circumstances where subsidiaries are not located domestically (see Kupiec and Wallison (2015) for an examination of U.S. SPOE implementation). In this light, treating bank subsidiaries as distinct entities in the event of failure may overcome some obstacles. For the MPOE approach to work, each subsidiary must be resolvable on a stand-alone basis. In this paper, we provide an empirical examination of the risk and funding characteristics of European subsidiary banks, contributing to the ongoing debate regarding SPOE and MPOE resolution.

The impact of cross-border banks on domestic banking competition, performance and efficiency has been thoroughly considered (Claessens and van Horen, 2012;

\footnotetext{
4 The legal framework underpinning the SRM is Article 114 of the Treaty on the Functioning of the European Union (2008). Further details on the development of the SRM may be found in Howarth and Quaglia (2014). Under the SRM, the SRB is the resolution authority for banks, both parent and subsidiary, with total assets greater than $€ 30$ billion. Moreover, if any subsidiary is deemed to be significant, then all subsidiaries, both domestic and cross-border, fall under the SRM.

5 For example, the United Kingdom has introduced the permanent resolution regime, supervised by the Bank of England.

${ }^{6}$ Equity will absorb losses in full before any debt liabilities are written down. Following equity, holders of alternative equity and alternative debt (such as contingent convertible liabilities or perpetual preferred equity) will be bailed-in, followed by subordinated and senior debt holders. Finally, depositors, excluding bank deposits with maturity less than 7 days, will be bailed-in.
} 
Claessens et al., 2001). In contrast, little is known about the differential risk and funding characteristics of parent banks relative to their domestic and cross-border subsidiaries from the perspective of resolution planning. Schoenmaker and Siegmann (2014) refer to the financial trilemma of cross-border recapitalization, whereby cross-border banking, national financial autonomy and financial stability are incompatible. Moreover, Gros and Schoenmaker (2014) highlight that supervisors' focus on preserving domestic parts of a bank during crisis. In the context of the present work, incentives for domestic regulators to resolve cross-border subsidiaries will likely be perturbed if such banks have higher risk and lower total loss absorbing capacity (TLAC) than other banks. Our findings indicate, however, that cross-border subsidiaries are generally better funded, providing partial support to MPOE resolution. In contrast domestic subsidiaries are found to be riskier in many dimensions, lending support to SPOE resolution.

European Banking Authority (EBA) guidelines relating to resolution do not propose specific strategies regarding the appropriateness of SPOE or MPOE resolution plans for individual institutions (European Banking Authority, 2014). ${ }^{7}$ In contrast, the SPOE strategy has been adopted by the FDIC as the mechanism for orderly liquidation of bank parent holding companies (Kupiec and Wallison, 2015). In light of the regulatory ambiguity regarding SPOE and MPOE within the EU28, the research findings detailed here highlight a crucial distinction between domestic and cross-border subsidiaries. We present evidence that, in recent years, cross-border subsidiaries have lower risk and stronger funding characteristics relative to domestic subsidiaries. Our findings indicate that cross-border subsidiaries are well equipped to deal with large writedowns, making them stronger candidates for MPOE resolution. The implication of these findings for policy makers is that there are grounds for making a clear distinction between crossborder and domestic subsidiaries, currently little emphasized under European resolution planning processes.

\footnotetext{
${ }^{7}$ The EBA membership comprises the current 28 members of the European Union (EU28).
} 
For a resolution planning process to successfully break links with the sovereign, a sufficient quantity of long-term capital must be committed. A worrying development, highlighted here, is the general decrease in capital available for bail-in witnessed over the period 2006 through 2014. An unintended consequence of introducing bail-in requirements has consequently been a shifting of risk to creditors such as depositors, with a convex payout to limited liability equity holders. Duran and Lazano-Vivas (2015) similarly document risk shifting in European banks over the period 2002-2009, but do not focus on subsidiary institutions or the impact of post-crisis changes in regulation. The implication for regulatory policy is a focus on broad capital thresholds to be applied to both subsidiary and parent banks as a pillar for the success of the resolution planning process. A further consideration, from the perspective of bank management and debt investors are the long-turn implications on funding costs, resulting from perceived risk shifting.

Our paper makes several important contributions to the literature. This is the first paper to consider European Union subsidiary banks in the context of bank resolution plans. Previous studies, such as Conlon and Cotter $(2016,2014)$ were limited to banks at the highest level of aggregation, omitting the considerable heterogeneity documented here for subsidiary banks. In contrast, our work provides an empirical characterization of risk and funding sources in Eurozone subsidiary banks, providing context on the prospects for and impacts from subordinate resolution. Second, while previous work has examined competition and profitability for cross-border and domestic banks (Claessens and van Horen, 2012; Claessens et al., 2001), this is the first study to focus on risk and funding characteristics of domestic and cross-border subsidiaries in the context of resolution planning. Our empirical findings point to many important distinctions in risk and funding between cross-border and domestic subsidiaries, relevant for regulators in assessing the appropriate means of resolution (SPOE or MPOE). Our final contribution relates to an assessment of the extent to which the implications from bail-in have changed over time. Specifically, we provide evidence 
that bank liabilities available for bail-in throughout European parent and subsidiary banks have decreased between 2006 and 2014, the period over which bail-in became mandatory. This relates to but expands the retrospective point-in-time bail-in analysis of Conlon and Cotter $(2014,2016)$ and Hüser (2018), to better understand the extent to which banks have altered their liability structure over time.

This paper is organized as follows. The data employed is described in Section 2. Empirical results are outlined in Section 3. Section 4 provides a discussion of policy implications and some concluding remarks.

\section{Data}

Data are obtained from Bankscope and are provided by Fitch Group and standardized for all banks using Bureau Van Dijk's universal banking model. ${ }^{8}$ The sample is filtered for listed and unlisted banks from 28 EU countries. Subsidiary banks are found by filtering for banks with a parent bank, either global or domestic, holding at least $50 \%$ of shares. Global and domestic subsidiaries are identified by comparing the parent and subsidiary country codes. The sample is further confined to banks with a loan-to-assets ratio greater than $20 \%$, to remove non-commercial bank entities. The resultant sample is dominated by commercial banks (63\%), followed by private banks (13.6\%), real estate and mortgage banks $(9.3 \%)$, savings banks $(8.3 \%)$ and cooperative banks $(5.8 \%)$. Data are gathered from 2006 through 2014, a period encompassing the global financial crisis, the Eurozone sovereign debt crisis and the introduction of the SRM and similar resolution frameworks in non-Eurozone countries. Only subsidiary banks with total assets greater than $€ 1$ billion are considered, providing coverage of $91.3 \%$ of European subsidiary bank assets. This lower threshold was selected due to a significant increase in missing data for banks with assets less than $€ 1$ billion.

A total of 513 subsidiary banks are examined, consisting of 286 domestic

\footnotetext{
${ }^{8}$ Bankscope data are accessed using the July 2016 disks provided by Bureau Van Dijk.
} 
subsidiaries and 227 cross-border subsidiaries, each having a (sometimes common) parent entity located within the EU (see Table A.1 for geographical breakdown). The largest number of cross-border subsidiary banks are located in Luxembourg (36), followed by Great Britain (26), Germany (22) and Poland (18). Considering domestic subsidiaries, 108 are located in France, 48 in Italy and 39 in Great Britain. Under the Eurozone Single Supervisory Mechanism9 (SSM) framework regulation, a bank is systemically important if the total value of its assets is greater than $€ 30$ billion (European Central Bank, 2014). For this reason, our sample is split, with cross-border banks with assets greater than $€ 30$ billion henceforth referred to as 'systemically important cross-border subsidiary’ (SICBS) banks, while those with assets less than $€ 30$ billion are defined as 'non-systemic cross-border subsidiary' (NSCBS) banks. Similarly, domestic banks are split into 'systemically important domestic subsidiary' (SIDS) banks and 'non-systemic domestic subsidiary' (NSDS) banks. Considering both cross-border (209) and domestic (265), the majority of subsidiary banks have total assets less than the significance threshold. Under the current SSM framework, a significant subsidiary bank will be supervised as part of the parent group, if the latter fulfils any of the criteria for significance.

In this study, we contrast risk and funding characteristics of subsidiaries (both domestic and cross-border) and parent banks. While no consensus exists regarding what constitutes a measure of banking risk, various facets of risk have been explored in the literature. Table A.2 describes the risk variables examined, the associated literature documenting their usage, and includes measures of insolvency risk, credit risk, liquidity risk and leverage risk. The various funding characteristics dominating bank's balance sheets are also described.

To assess the fitness of institutions from the perspective of resolution planning, we estimate each banks' total loss absorbing capacity (TLAC). TLAC has been proposed

\footnotetext{
9 The operations and credibility of the SSM design has been examined in detail (Gren et al., 2015). The national preferences regarding the threshold for direct ECB supervision are discussed in Howarth and Quaglia (2016).
} 
by the Financial Stability Board as part of an international standard for global systemically important banks (G-SIBs) (Financial Stability Board, 2015). It defines a requirement for available bail-in liabilities under resolution at G-SIBS. Of importance to this study, host authorities of cross-border banks must ensure that there is sufficient loss-absorbing and recapitalization capacity available to subsidiaries. The European Banking Authority (EBA) have proposed a minimum requirement for own funds and eligible liabilities (MREL), imposing bank-specific MREL targets for the majority of the largest and most complex banks including all G-SIBs and banks with resolution plans. Under a revised 'harmonised application' of MREL, the EBA has proposed to also implement the TLAC standard within the European Union (European Banking Authority, 2016). TLAC is comprised of instruments qualifying as tier 1 or tier 2 capital, in addition to unsecured senior and subordinated debt with a minimum maturity of at least 1 year (Kupiec, 2016). As highlighted by Huertas (2016), differences between TLAC and MREL predominantly relate to the latter's incorporation of deposits under certain circumstances, not impacting our findings here. 


\section{Empirical Findings}

\subsection{Subsidiary and parent banks}

The objective of this study is to develop an understanding of subsidiary banks from both a risk and funding perspective in the context of resolution planning. We first contrast solvency risk, credit risk, liquidity risk and capital adequacy of subsidiary banks with parent banks. We follow this by comparing their funding characteristics.

Table 1 demonstrates significant differences between subsidiaries and parent banks on average. Considering cross-border subsidiaries first, we find that they have significantly lower insolvency risk (high Z-Score), greater quantities of liquid assets and higher tier 1 capital on average. They are less diversified in terms of revenue streams (higher loans to total assets) and earn lower rents than the parent group (lower net interest margin). Turning to bank funding characteristics, overseas subsidiaries are differentiated from parents in many dimensions. NSCBS (SICBS) hold a significant $3.72 \%(2.19 \%)$ more equity than their parents on average. Parent banks of SICBS hold greater quantities of alternative equity. NSCBS hold a significantly greater quantity of subordinated, senior and alternative debt than parent banks. The most striking finding is that NSCBS (SICBS) rely on customer deposits to supply $8.56 \%$ (5.95\%) more of their total funding than parents on average. A higher share of such retail funding in subsidiaries has been associated with lower bank default risk (Anginer et. al., 2017), providing an initial indication regarding the suitability of cross-border subsidiaries for MPOE resolution plans. Reliance on bank deposits is $18.28 \%$ (13.22\%) greater than for parent banks in NSCBS (SICBS) subsidiaries, but presumably largely endowed by parent institutions highlighting a potential funding weakness.

[Table 1]

Domestic subsidiary banks (panel ii) are similarly distinct from parent banks across many dimensions. In terms of risk-related characteristics, they have less diversified revenue streams, evidenced by significantly greater loans. Higher loan loss reserves 
point to greater credit risk. The proportion of liquid assets held by SIDS is considerably lower on average than parent banks. Risk-weighted tier 1 capital is $4.13 \%$ (3.88\%) greater for NSDS (SIDS) than parent banks. The latter result carries over to domestic subsidiary funding characteristics, which have significantly greater equity, alternative equity and alternative debt than their parent banks. SIDS also hold an average $3.95 \%$ more senior debt than parent banks. Common with our findings for cross-border subsidiaries, domestic subsidiaries have much greater reliance on customer and bank deposits relative to parent banks.

During the global financial crisis, parent banks were not a significant source of strength to their subsidiaries (De Haas and van Lelyveld, 2014), highlighting the importance of subsidiaries having strong internal characteristics, especially stand-alone subsidiaries (Schoenmaker, 2018). The findings above demonstrate significant differences between parent banks and their cross-border and domestic subsidiaries. Furthermore, the composition of funding described here for parent banks is in keeping with that of Conlon and Cotter (2014). While cross-border subsidiaries present lower risks across many dimensions (insolvency, liquidity), domestic subsidiaries have characteristics indicative of greater risks than parent banks (credit risk, liquidity). Funding patterns are also less stable across domestic banks, relative to parent banks. In contrast, similar funding patterns are evident for cross-border and parent banks, important in the context of resolution planning resilience for cross-border subsidiaries. This is also important as, if the parent bank encounters financial distress, the subsidiary may be required to provide it with resources (Karamichailidou and Mayes, 2016). These findings illustrate some distinctions between domestic and cross-border subsidiaries relative to parent banks, with conceivable implications for the appropriate resolution planning process. We next investigate this distinction and implications in detail, contrasting cross-border and subsidiary banks. 


\subsection{Cross-Border and Domestic Subsidiaries}

Much has been made of the challenges of supervising and regulating banks with cross-border activities (Hardy and Nieto, 2011). While this implicitly encompasses cross-border subsidiaries, little is known about domestic subsidiaries. Under the current EBA resolution framework, no distinction between domestic and cross-border subsidiaries is made (European Banking Authority, 2014). If domestic and cross-border subsidiaries present differential characteristics, however, a one-size-fits-all approach may be inadequate.

We first contrast the funding characteristics of domestic and cross-border subsidiaries, to understand cross-sectional and time series differences, Figure 1. Our analysis is segmented according to bank size into systemic and non-systemically important banks, in keeping with the ECB definition of significance. Panels (i) and (ii) investigate the equity and debt held by subsidiary banks, so-called TLAC or high quality capital. For both systemic and non-systemically important subsidiaries, a significant proportion of TLAC comes from equity and senior debt, with alternative forms of capital and subordinated debt playing a more minor role. While aggregate high quality capital has decreased in banks in recent years, we observe a relative increase in funding for SICBS in 2013 and 2014. This is attributed primarily to increased equity capital, of central importance for successful resolution planning.

[Figure 1]

Considerable funding differences are evident for non-systemically important banks. NSCBS have up to $9 \%$ less TLAC than domestic counterparts. Furthermore, we find decreasing TLAC in both cases since 2008, a point we examine in greater detail later. The predominate differentiating funding characteristic for non-systemic banks is the quantity of senior debt held, also steadily decreasing over time. Two implications relating to the introduction of bail-in rules arise. First, banks have decreased their reliance on senior debt over time increasing the likelihood of depositor bail-in. Second, in line with large increases in bank credit spreads observed with the introduction of bailin (Alemany et. al. 2015), markets require a greater yield on bank debt, altering the 
attractiveness of debt as a funding source for banks.

Next, we contrast the reliance on deposits between cross-border and domestic subsidiaries. In keeping with findings for high quality capital, systemically important subsidiaries count on deposits to a similar extent. The mix of deposits, however, has evolved over time. Systemically important subsidiaries have become more reliant on customer deposits, with commensurate decrease in deposits from banks. ${ }^{10}$ This highlights that parent banks are, in recent years, less willing or able to provide subsidiaries with necessary deposits, compelling subsidiaries to focus on sticky customer deposits. Moreover, we observe a common increase in repo and cash collateral counted as deposits, in line with previous findings of increasing trading volume in repo markets over a similar period (Mancini et. al., 2016). Striking differences are evident for non-systemic subsidiaries. First, NSCBS are significantly less dependent upon deposits from banks than NSDS. Second, total deposit funding for NSDS is up to $14 \%$ greater than NSCBS. Finally, NSCBS banks have greater reliance on repos and cash collateral. In response to the dramatic decrease in TLAC attributed to non-systemic subsidiaries, deposit funding has increased in recent years.

While systemically important subsidiaries have similar aggregate funding, important differences in the makeup, especially surrounding equity capital, are evident. Very notable distinctions in the funding levels and composition are apparent for nonsystemically important subsidiaries. As highlighted by Khan et. al. (2017), a notable relationship between funding liquidity and bank risk taking exists, highlighting the importance of considering both jointly. To this end, we examine various risk characteristics for SICBS (vertical axis) and SIDS (horizontal axis) in Figure 2 over the period 2008 through 2014. ${ }^{11}$ While all subsidiaries are considered here, a sample

\footnotetext{
10 While only a small number of studies have examined the nature of funding in subsidiary banks, Allen et. al. (2014) demonstrate decreasing reliance of UniCredit bank on intragroup deposits over time, similar to that documented here.

${ }^{11}$ Non-systemically important subsidiaries were also examined. NSDS carried less insolvency risk up to 2011, NSCBS display greater Z-scores from that point onwards. NSCBS have greater credit risk than NSDS, in contrast to findings for large banks. Similar to large subsidiaries, NSCBS have lower liquidity,
} 
matched on the same parent will be examined later. Many noteworthy differences are evident. For instance, SIDS were more solvent (greater Z-score) in the early years of the sample, but SICBS have greater solvency in recent years. SICBS earn higher net interest margin, synonymous with greater rent earning ability and previously linked with market power (Amidu and Wolfe, 2013). Finally, while SICBS hold more equity at all points in time, tier 1 risk weighted capital has deteriorated in recent years. These findings highlight that SIDS have greater insolvency risk, greater credit risk, earn lower margins and are, generally, less well capitalized than SICBS.

[Figure 2]

Given the evidence for differing risk and funding characteristics between subsidiaries, this raises the question of whether domestic and cross-border subsidiaries belonging to a common parent bank have differential traits. In Table 2 matched banks having common parent are examined. For brevity, only data from the start of the financial crisis (2008) and the most recent available year (2014) are detailed. Several distinguishing characteristics are evident.

Considering risk characteristics first, cross-border subsidiaries are found to have significantly lower insolvency risk (higher Z-score) than matched domestic relations. Domestic subsidiaries have greater exposure to traditional lending than their crossborder counterparts, indicative of decreased diversification. A number of distinctions may be made according to the year studied. In 2008 cross-border subsidiaries had greater loan loss reserves and larger quantities of liquid assets. By 2014 both risk characteristics had reversed but are not significant. In 2014, cross-border subsidiaries had tier 1 capital of $18.13 \%$, a significant $2.67 \%$ greater than matched domestic subsidiaries.

[Table 2]

Contrasting the funding characteristics of matched banks, various differences are

greater net interest margin and are better capitalized than domestic. 
evident. First, cross-border banks held a significant $1.21 \%$ more equity in 2008 but this gap was insignificant by 2014, a consequence of an increasing proportion of equity for domestic subsidiaries. No significant differences in subordinated or senior debt are evident. Domestic subsidiaries fulfilled $45.53 \%$ of their funding requirements from customer deposits in 2008, a significant $3.68 \%$ greater than cross-border banks. By 2014, cross-border subsidiaries raised the majority of their funding from customer deposits, 3.93\% more than domestic brethren. These findings are reversed for bank deposits. The increased reliance of cross-border subsidiaries on sticky customer deposits provides them with lower funding liquidity risk but has been associated with increased risk taking for US banks (Khan et. al., 2017). Such an increase in risk taking is not evident here for cross-border subsidiaries. Considering funding dynamics over time, similar quantities of equity and senior debt are employed but quantities of senior debt for both forms of subsidiary have decreased markedly. To compensate this, a much greater reliance on customer deposits is evident, especially in the case of cross-border subsidiaries.

Bolton and Oehmke (2016) contend that the trade-off between SPOE and MPOE resolution plans depends upon the nature of the bank's underlying business. Examining this for subsidiaries, we find a variety of distinct differences in terms of risk and funding. Akin to the findings of Anginer et. al. (2017), we document domestic subsidiaries as having lower retail deposit funding and greater insolvency risk than cross-border subsidiaries. Under these circumstances, SPOE resolution would be a more appropriate regime for domestic subsidiaries, while the presence of a common national resolution authority would make SPOE resolution more appropriate. In contrast, our findings point to the appropriateness of MPOE for cross-border subsidiaries in many regards. First, such subsidiaries are less risky and more robustly funded than domestic subsidiaries. This should mean, all things being equal, that resolution is less likely but more straightforward if required. Second, given the evidence for a strong capital base, especially for large systemically important cross-border subsidiaries, MPOE resolution 
would appear to be more workable. We next investigate the implications for the resolution planning process, by studying the robustness to bail-in.

\subsection{Bail-In Implications}

The large paper losses realized by many European banks over the period studied resulted in huge writedowns in many institutions. Conlon and Cotter (2014) estimate that parent banks in the largest European nations had realized impairments of $€ 535$ billion between 2008 and 2012, while Conlon and Cotter (2016) indicate unequal disbursement of losses across Euro area countries. We build on these studies by examining the impact of bail-in on subsidiary banks, accounting for the considerable heterogeneity in risk and funding characteristics described above.

Proportional writedowns and conversions for cross-border and domestic subsidiary banks are examined in Table 3 , accounting for conversion to equity required to ensure a 3\% leverage ratio post bail-in. Analysis is broken out for systemically important banks and shown during the global financial crisis (2008) and the most recent year (2014). Apart from the case of NSCBS with writedowns of 5\%, equity, alternative equity and alternative debt investors would have been fully bailed-in. For this reason, detailed results are limited to the impact on senior debt holders and depositors.

[Table 3]

For a 5\% writedown, the senior debt of SICBS would have been bailed-in to the tune of $23 \%$ in 2008, comparable with the evidence provided by Conlon and Cotter (2016) for nationalized parent banks. By 2014, senior debt holders of SICBS would only have experienced writedowns of the order of $8 \%$, while SIDS senior debt holders would have required bail-in of $22 \%$. Similar evidence is found for larger writedown requirements. For extreme, and unlikely, losses of $20 \%$, all senior debt holders would have been fully bailed-in. Depositors in SICBS would have been bailed in by $8 \%$ but bail-in for depositors in SIDS would have amounted to $13 \%$ of the total. The evidence points to a more resilient balance sheet in the case of cross-border subsidiaries, but a decrease in resilience for domestic banks by 2014. 
For non-systemic subsidiaries, bail-in requirements would have been lower, for the same level of writedown. In the case of NSCBS, bail-in requirements are lower in 2014 than 2008, commensurate with an increase in the proportion of high-quality equity capital. For a $5 \%$ asset writedown, equity holders would have been bailed-in by $55 \%$, with no impact on other claimants. In contrast, NSDS equity investors would be fully written down, with senior debt holders experiencing losses of 11\%. Similar findings are indicated at higher writedown levels for 2014. Furthermore, NSDS investors would have encountered smaller losses in 2008 than NSCBS, signaling a phase change in funding structure, something we investigate next.

We now evaluate the level of writedown that parent banks, domestic and crossborder subsidiaries can withstand before depositors are impacted, Figure 3 . This acts as a baseline for TLAC at each bank type, and is the sum of equity, alternative equity and debt, subordinated and senior debt divided by total assets. Considering cross-sectional differences first, we find that domestic banks, both systemic and non-systemic, can absorb larger losses than parent banks. Similar findings are evident for SICBS, especially in recent years. Contrasting domestic and cross-border subsidiary banks, some pertinent results emerge. While domestic subsidiaries had up to $7.8 \%$ (1.6\%) more loss absorbing capacity for non-systemic (systemic) subsidiaries in 2008, this differential has deteriorated over time. In fact, for SIDS, loss absorbing capacity is $2.56 \%$ lower in 2014 than commensurate cross-border subsidiaries. The latter finding ties in with results previously presented, demonstrating recent funding fragility for domestic subsidiaries. Linking this with previous work on bail-in in centralized and decentralized banks, Bolton and Oehmke (2016), these results provide further support for SPOE resolution in more centralized domestic subsidiaries.

The most significant finding detailed in Figure 3 is the decrease in loss absorbing capacity found for all bank types between 2006 and 2014. This is particularly striking for domestic subsidiaries where losses of up to $27.4 \%$ would have been required before depositors were impacted in 2006. In contrast, a loss of $17.6 \%$ would have been sufficient to eliminate all loss absorbing capacity in 2014. Similar conclusions are 
evident for parent banks, where loss absorbing capacity diminished by about $7 \%$ over the same period. The decrease in loss absorbing capacity for cross-border banks, while not as substantial, is between $3 \%$ and $5 \%$, with an upturn observed in recent years.

[Figure 3]

The introduction of resolution plans and, in particular, bail-in has the aim of reducing or eliminating future tax-payer funding of bank losses. Our results indicate that this strategy has been associated with a period during which banks have decreased the quantity of high quality loss absorbing capacity. Whether the introduction of bail-in has been the driver of this decrease is outside the scope of this study, but the prevalent decreasing trend poses a strong challenge to the future success of any resolution planning process.

\section{Conclusions and Discussion}

In this paper we examine European subsidiary banks with the objective of classifying their relative risk and resilience to resolution. European domestic and crossborder subsidiaries are contrasted with each other and with their parent bank, both in the cross-section and over time. Our analysis provides context on the suitability of SPOE and MPOE resolution for subsidiary banks.

Contrasting subsidiary banks with their parent banks, a range of distinctions are observed both in terms of risk and funding. In particular, cross-border subsidiaries hold greater quantities of high-quality capital relative to their parent banks, alleviating one of the major concerns surrounding MPOE resolution. Our findings point to sufficient ability of cross-border subsidiaries to withstand writedowns without recourse to a parent. Results for domestic subsidiaries are less clear. Directly contrasting domestic and cross-border subsidiaries, we find that the latter have lower insolvency and credit risks in recent years, but inferior liquidity relative to domestic subsidiaries. We further provide a distinction between loss absorbing capital and deposits for systemic and non- 
systemically important subsidiaries.

The implications of bail-in for banking investors are also examined. We find that cross-border subsidiaries are in a relatively stronger position to absorb writedowns (even substantial ones) of liabilities compared to domestic counterparts. Contrasting loss absorbing capacity over time, we witness a distinct decrease in the proportions of available TLAC across all forms of bank examined.

There are several implications from our findings for regulators. First, our findings point to the relative appropriateness of SPOE resolution plans for domestic subsidiaries. While their funding structure is stronger than parent banks on average, aggregate analysis indicates some deficiencies in recent years. Indeed, their funding tends to be more fragile than that of cross-border counterparts. Moreover, evidence from the bailin analysis points to greater likelihood of impact on depositors from writedowns. Additionally, parent banks may be owners of subordinated or senior debt issued by subsidiary banks, simplifying the resolution planning process. In contrast, cross-border banks meet many of the criteria for MPOE resolution. We find that such banks are less risky across many dimensions and are better positioned to absorb write-downs. Moreover, in light of differential resolution incentives, the ability of such subsidiaries to absorb losses simplifies the problem of cross-border resolution.

We conclude our analysis with two points of caution for future developments in bank resolution planning. While the analysis indicates that subsidiary banks have strong funding structures relative to parents, short-term liquidity may be a concern. To ensure that subsidiary banks are resilient to shocks, their liquidity should be such that they are not dependent upon parent banks during periods of market turmoil. Second, the evidence for decreased loss absorption capacity across all bank types examined relates to recent findings of risk-shifting within European banks (Duran and Lozano-Vivas, 2015), potentially undermining regulatory efforts to strengthen the core banking system. 


\section{References}

Abedifar, P., Molyneux, P., Tarazi, A. (2013). Risk in Islamic banking. Review of Finance, 17(6), 2035-2096.

Agusman, A., Monroe, G.S., Gasbarro, D., Zumwalt, J.K. (2008). Accounting and capital market measures of risk: Evidence from Asian banks during 1998-2003. Journal of Banking and Finance, 32(4), 480-488.

Allen, F., Hryckiewicz, A., Kowalewski, O., Tümer-Alkan, G. (2014) Transmission of financial shocks in loan and deposit markets: Role of interbank borrowing and market monitoring. Journal of Financial Stability, 15, 112-126.

Alemany, A., Ballester, L., \& González-Urteaga, A. (2015). Volatility spillovers in the European bank CDS market. Finance Research Letters, 13, 137-147.

Amidu, M., \& Wolfe, S. (2013). The impact of market power and funding strategy on bank-interest margins. European Journal of Finance, 19(9), 888-908.

Anginer, D., Cerutti, E., \& Martínez Pería, M. S. (2017). Foreign bank subsidiaries' default risk during the global crisis: What factors help insulate affiliates from their parents? Journal of Financial Intermediation, 29, 19-31.

Beltratti, A., Stulz, R. M. (2012). The credit crisis around the globe: Why did some banks perform better? Journal of Financial Economics, 105(1), 1-17.

Bolton, P., Oehmke, M. (2016). Bank resolution and the structure of global banks. Columbia University Working Paper.

Casu, B., Girardone, C., \& Molyneux, P. (2015). Introduction to Banking (2nd Edition). Essex, United Kingdom: Pearson.

Claessens, S., van Horen, N. (2012). Being a foreigner among domestic banks: Asset or liability? Journal of Banking and Finance, 36(5), 1276-1290. 
Claessens, S., Demirguc-Kunt, A., Huizinga, H. (2001). How does foreign entry affect domestic banking markets? Journal of Banking and Finance, 25, 891-911.

Conlon, T., Cotter, J. (2014). Anatomy of a bail-in. Journal of Financial Stability, 15, 257-263.

Conlon, T., Cotter, J. (2016). Euro area bank resolution and bail-in: Intervention, triggers and writedowns. Pages 78-99 of: Castaneda, J.E., Mayes, D.G., Wood, G. (eds), European Banking Union: Prospects and Challenges. London \& New York: Routledge.

De Haas, R., van Lelyveld, I. (2014). Multinational banks and the global financial crisis: Weathering the perfect storm? Journal of Money, Credit and Banking, 46(1), 333364.

Duran, M.A., Lozano-Vivas, A. (2015). Moral hazard and the financial structure of banks. Journal of International Financial Markets, Institutions and Money, 34, 2840.

European Banking Authority. (2014). EBA final draft regulatory technical standards on the content of resolution plans and the assessment of resolvability. $E B A / R T S / 2014 / 15$

European Banking Authority. (2016). Final report on MREL: Report on the implementation and design of the MREL framework. EBA-Op-2016-21.

European Central Bank. (2014). Regulation (EU) No 468/2014 of the European Central Bank of 16 April 2014 establishing the framework for cooperation within the Single Supervisory Mechanism between the European Central Bank and national competent authorities and with national designated authorities. 
Financial Stability Board. (2015). Principles on loss-absorbing and recapitalisation capacity of G-SIBs in resolution - Total loss-absorbing capacity (TLAC) term sheet, November 2015.

Goddard, J., Molyneux, P., Wilson, J. O.S., Tavakoli, M. (2007). European banking: An overview. Journal of Banking \& Finance, 31(7), 1911-1935.

Goddard, J., Molyneux, P., Wilson, J.O.S. (2009). The financial crisis in Europe: Evolution, policy responses and lessons for the future. Journal of Financial Regulation and Compliance, 17(4), 362-380.

Gren, J., Howarth, D., Quaglia, L. (2015). Supranational banking supervision in Europe: The construction of a credible watchdog. Journal of Common Market Studies, 53(S1), 181-199.

Gros, D., Schoenmaker, D. (2014). European deposit insurance and resolution in the banking union. Journal of Common Market Studies, 52(3), 529-546.

Hardy, D.C., Nieto, M.J. (2011). Cross-border coordination of prudential supervision and deposit guarantees. Journal of Financial Stability, 7(3), 155-164.

Howarth, D., Quaglia, L. (2016). Internationalised banking, alternative banks and the Single Supervisory Mechanism, West European Politics, 39(3), 438-461

Howarth, D., Quaglia, L. (2014). The steep road to European banking union: Constructing the single resolution mechanism. Journal of Common Market Studies, 52, 125-140.

Huertas, T. (2016). European bank resolution: Making it work! Centre for European Policy Studies Working Paper.

Hüser, A.-C., Hałaj, G., Kok, C., Perales, C., van der Kraaij, A. (2018). The systemic implications of bail-in: A multi-layered network approach. Journal of Financial Stability, Forthcoming. 
Karamichailidou, G., Mayes, D.G. (2016). Plausible recovery and resolution plans for cross-border financial institutions. Pages 38-66 of: Castaneda, J.E., Mayes, D.G., Wood, G. (eds), European Banking Union: Prospects and Challenges. London \& New York: Routledge.

Khan, M. S., Scheule, H., \& Wu, E. (2017). Funding liquidity and bank risk taking. Journal of Banking and Finance, 82, 203-216.

Kupiec, P. H. (2016). Will TLAC regulations fix the G-SIB too-big-to-fail problem? Journal of Financial Stability, 24, 158-169.

Kupiec, P., Wallison, P. (2015). Can the "Single Point of Entry" strategy be used to recapitalize a systemically important failing bank? Journal of Financial Stability, 20, 184-197.

Mancini, L., Ranaldo, A., \& Wrampelmeyer, J. (2016). The euro interbank repo market. Review of Financial Studies, 29(7), 1747-1779.

Schoenmaker, D. (2017). Resolution of international banks: Can smaller countries cope? International Finance, 21(1), 39-54.

Schoenmaker, D., Siegmann, A. (2014). Can European bank bailouts work? Journal of Banking \& Finance, 48, 334-349.

The European Parliament and the Council of the European Union. (2014). Directive 2014/59/EU of the European parliament and of the council establishing a framework for the recovery and resolution of credit institutions and investment firms. Official Journal of the European Union, 15 May 2014.

Trichet, J.-C. (2010). State of the Union: The financial crisis and the ECB's response between 2007 and 2009. Journal of Common Market Studies, 48, 7-19. 
(i) High Quality Capital, Non-Systemically Important Banks

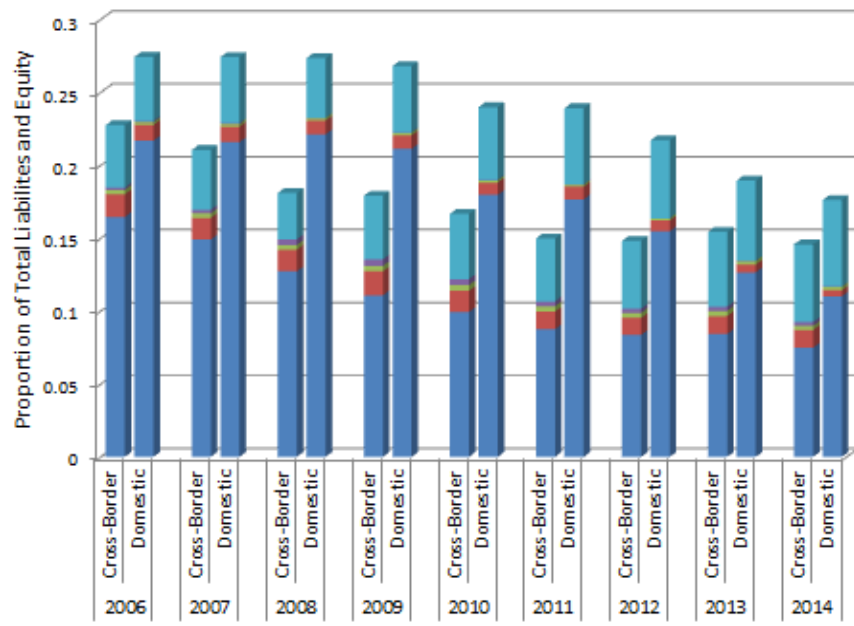

(iii) Deposits, Non-Systemically Important Banks (ii) High Quality Capital, Systemically Important Banks

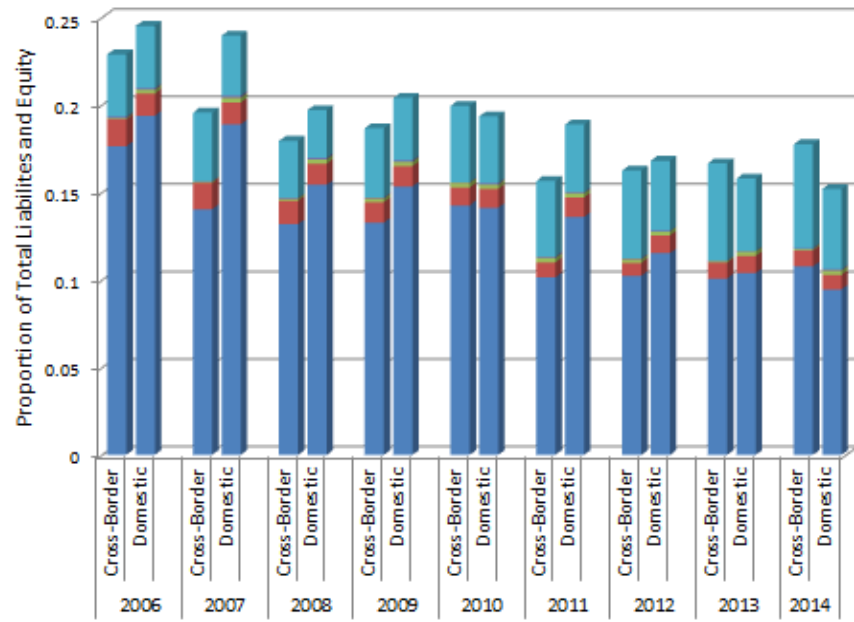

(iv) Deposits, Systemically Important Banks

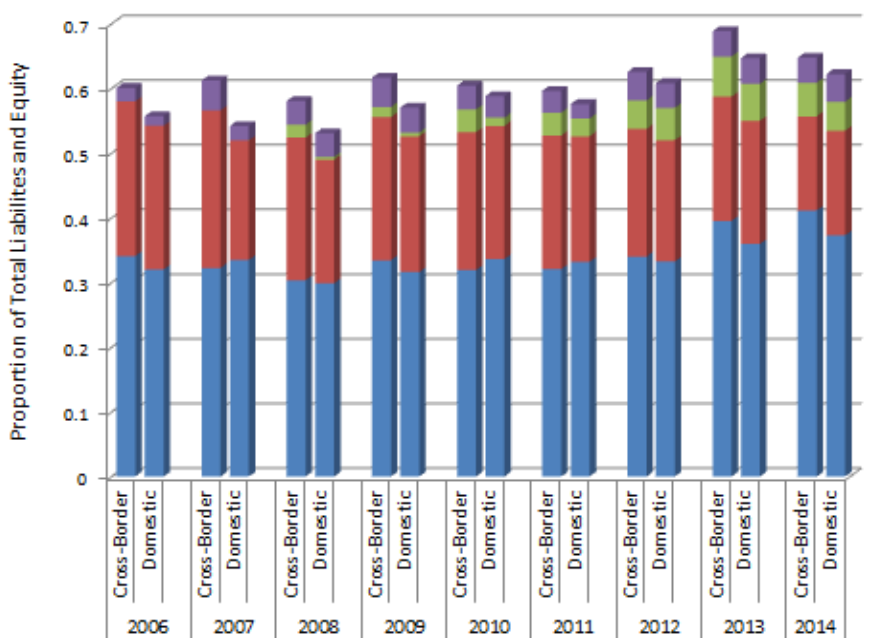

Figure 1: Funding of Subsidiary Banks (2006-2014).

Funding sources are contrasted for cross-border and domestic subsidiary banks on an aggregate basis. Each funding source is expressed as a proportion of total bank liabilities and equity. Banks are broken into systemic and non-systemic subsidiaries using a threshold of $€ 30$ billion. Crossborder subsidiaries are those where the parent bank and subsidiary are located in different countries. Domestic subsidiaries are located in the same country as the parent bank. Banks are selected from the 28 member states of the EU. 
(i) Z-Score

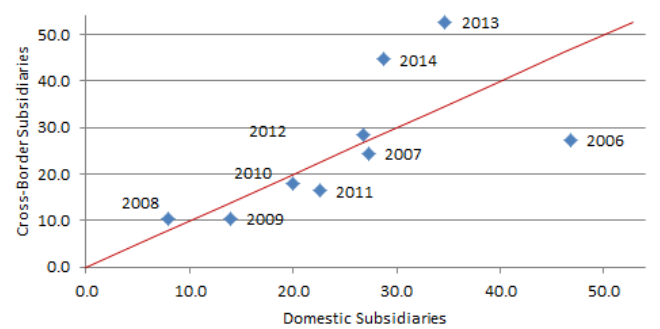

(iii) Loan Loss Reserves to Gross Loans

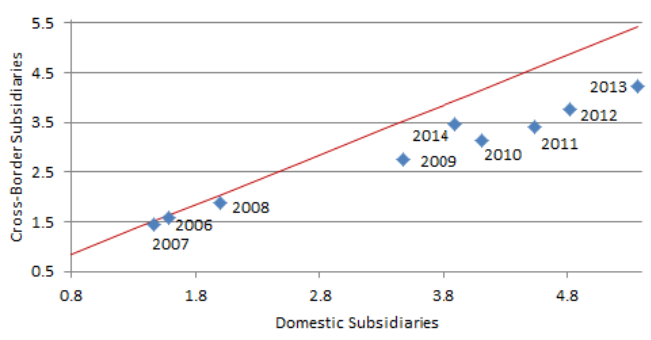

(v) Liquid Assets to Deposits and Short-Term Funding

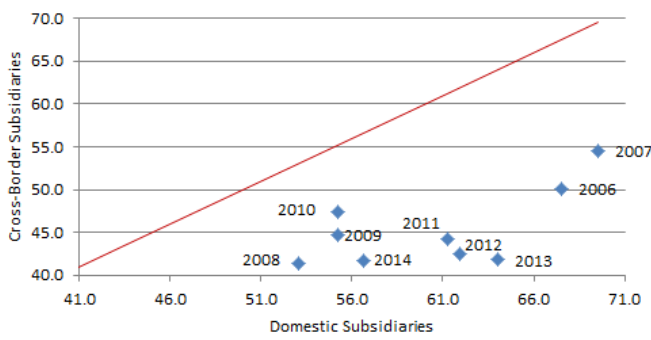

(vii) Equity to Total Assets

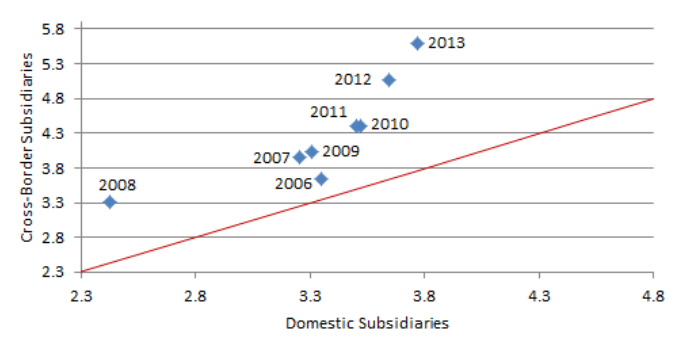

(ii) Net Loans to Total Assets

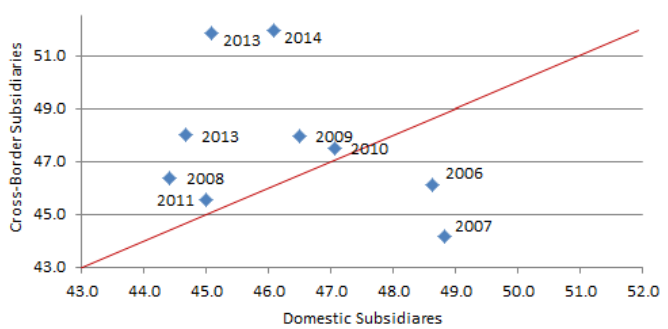

(iv) Loan Loss Provisions to Gross Loans

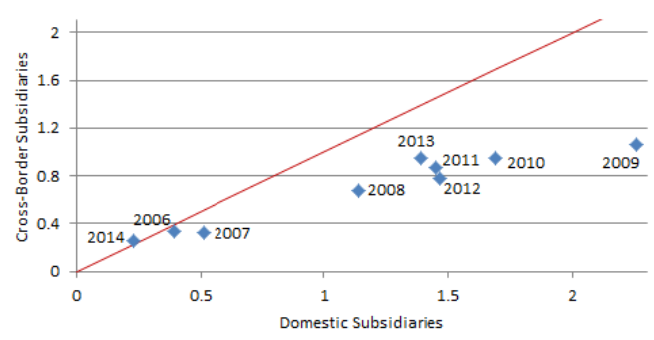

(vi) Net Interest Margin

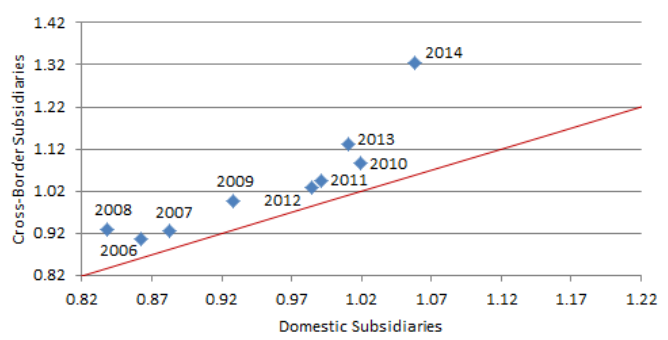

(viii) Tier 1 Capital Ratio

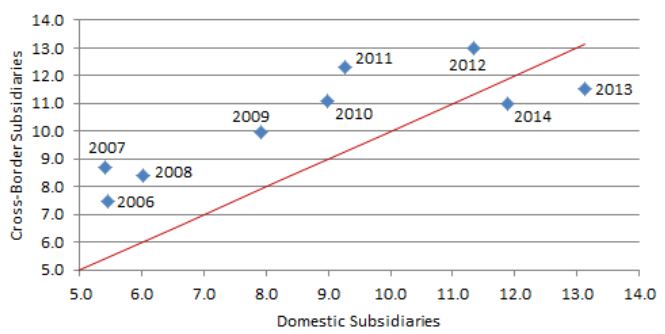

Figure 2: Risk Comparison of Systemically Important Cross-Border and Domestic Subsidiary Banks (2006-2014).

Various risk characteristics are contrasted for systemically important cross-border and domestic subsidiary banks (assets over $€ 30$ billion) each year from 2006 through 2014 . Equal risk is indicated by the diagonal (red) line in each plot. Observations below the red line indicate that characteristics associated with domestic subsidiaries are greater, while above the line cross-border subsidiary characteristics are greater. Cross-border subsidiaries are those where the parent bank and subsidiary are located in different countries. Domestic subsidiaries are located in the same country as the parent bank. Banks are selected from the 28 member states of the EU. 

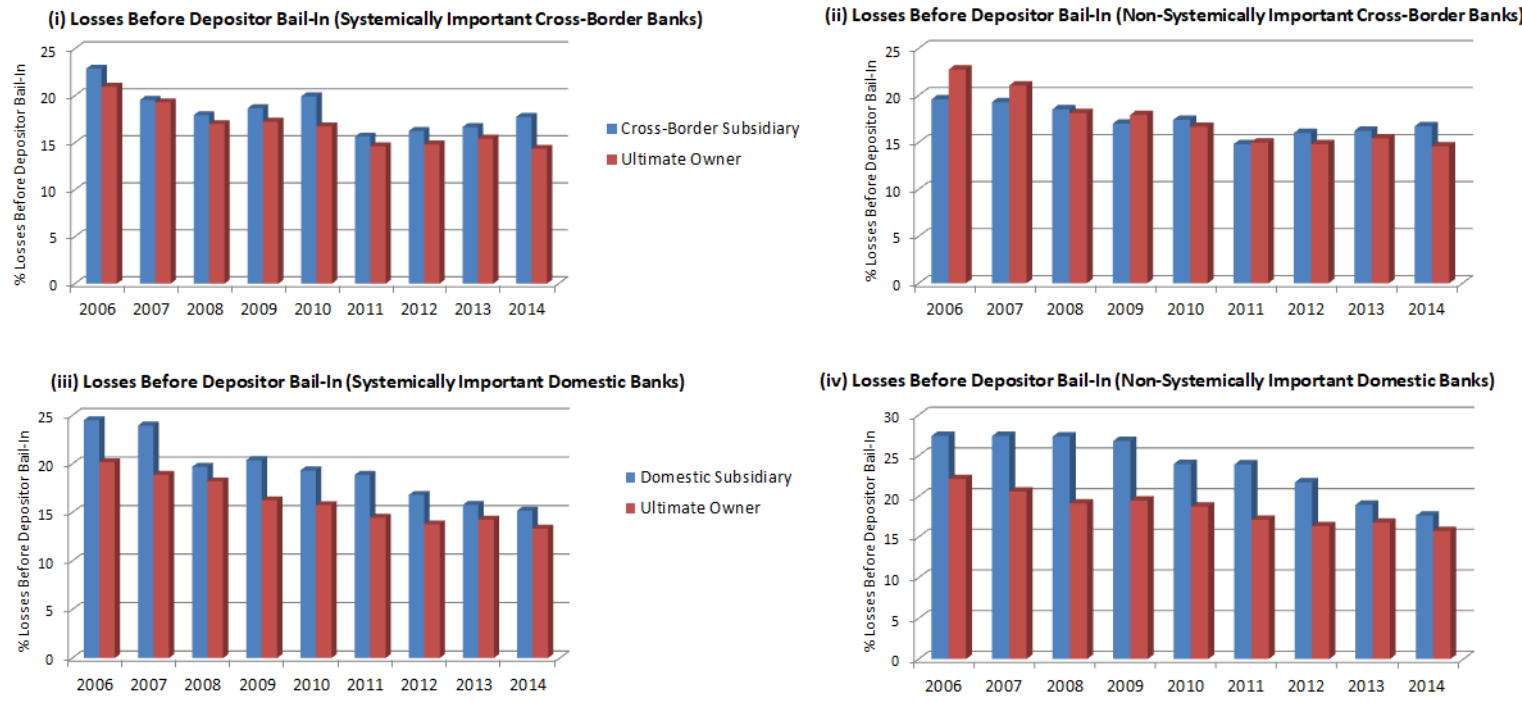

Figure 3: Bail-in Threshold for Depositors (2006-2014).

The percentage losses as a proportion of total bank assets before depositor bail-in is estimated. For crossborder and domestic subsidiaries the percentage losses are compared with those of the parent bank. Banks are characterized as systemic and non-systemically important ( $€ 30$ billion threshold). Cross-border subsidiaries are those where the parent bank and subsidiary are located in different countries. Domestic subsidiaries are located in the same country as the parent bank. Banks are selected from the 28 member states of the EU. 
(i) Cross-Border Subsidiaries

\begin{tabular}{lcccccc} 
& \multicolumn{3}{c}{ Non-Systemically } & Important & \multicolumn{2}{c}{ Systemically Important } \\
\hline & $\begin{array}{c}\text { Overseas } \\
\text { Subsidiary }\end{array}$ & $\begin{array}{c}\text { Parent } \\
\text { Bank }\end{array}$ & $\begin{array}{c}\text { Equality } \\
\text { of Means }\end{array}$ & $\begin{array}{c}\text { Overseas } \\
\text { Subsidiary }\end{array}$ & $\begin{array}{c}\text { Parent } \\
\text { Bank }\end{array}$ & $\begin{array}{c}\text { Equality } \\
\text { of Means }\end{array}$ \\
\hline Z-Score & 311.74 & 65.69 & $0.000^{* * *}$ & 139.22 & 45.70 & $0.001^{* * *}$ \\
Net Loans to Total Assets & 57.31 & 52.07 & $0.000^{* * *}$ & 53.24 & 47.43 & $0.001^{* * *}$ \\
Loan Loss Reserves & 3.85 & 3.82 & 0.94 & 2.91 & 3.34 & 0.20 \\
Loan Loss Provisions & 1.08 & 1.03 & 0.80 & 1.16 & 0.92 & 0.32 \\
Liquid Assets & 51.47 & 38.46 & $0.000^{* * *}$ & 69.11 & 44.57 & $0.001^{* * *}$ \\
Net Interest Margin & 1.38 & 1.88 & $0.004^{* * *}$ & 0.67 & 1.36 & $0.014^{* *}$ \\
Tier 1 Capital Ratio & 12.14 & 10.69 & $0.000^{* * *}$ & 11.51 & 10.98 & 0.24 \\
& & & & & & \\
Liabilities (over total liabilities & and equity) & & & & & \\
Equity & 10.34 & 6.62 & $0.000^{* * *}$ & 6.58 & 4.39 & $0.000^{* * * *}$ \\
Alternative Equity & 0.84 & 0.75 & 0.84 & 0.26 & 0.67 & $0.000^{* * *}$ \\
Alternative Debt & 0.94 & 0.51 & $0.044^{* *}$ & 1.57 & 0.52 & $0.059^{*}$ \\
Subordinated Debt & 2.56 & 1.50 & $0.000^{* * *}$ & 1.30 & 1.44 & 0.32 \\
Senior Debt & 14.41 & 12.70 & $0.068^{*}$ & 13.33 & 13.21 & 0.92 \\
Customer Deposits & 49.92 & 41.36 & $0.000^{* * *}$ & 42.49 & 36.54 & $0.000^{* * *}$ \\
Bank Deposits & 30.00 & 11.72 & $0.000^{* * *}$ & 22.57 & 9.35 & $0.000^{* * *}$ \\
Repos and Cash Collateral & 6.28 & 7.29 & 0.20 & 7.28 & 8.21 & 0.34 \\
Other Deposits & 11.43 & 7.57 & $0.002^{* * *}$ & 6.41 & 5.93 & 0.59
\end{tabular}

(ii) Domestic Subsidiaries

\begin{tabular}{lcccccc} 
& \multicolumn{3}{c}{ Non-Systemically Important } & \multicolumn{2}{c}{ Systemically Important } \\
\hline & $\begin{array}{c}\text { Domestic } \\
\text { Subsidiary }\end{array}$ & $\begin{array}{c}\text { Parent } \\
\text { Bank }\end{array}$ & $\begin{array}{c}\text { Equality } \\
\text { of Means }\end{array}$ & $\begin{array}{c}\text { Domestic } \\
\text { Subsidiary }\end{array}$ & $\begin{array}{c}\text { Parent } \\
\text { Bank }\end{array}$ & $\begin{array}{c}\text { Equality } \\
\text { of Means }\end{array}$ \\
\hline Z-Score & 87.89 & 100.27 & 0.59 & 77.55 & 66.29 & 0.30 \\
Net Loans to Total Assets & 61.04 & 55.63 & $0.000^{* * *}$ & 59.56 & 41.79 & $0.000^{* * *}$ \\
Loan Loss Reserves & 4.29 & 3.61 & $0.048^{* *}$ & 3.61 & 2.19 & $0.000^{* * *}$ \\
Loan Loss Provisions & 1.01 & 0.98 & 0.89 & 1.79 & 0.71 & 0.16 \\
Liquid Assets & 42.26 & 39.02 & 0.23 & 46.70 & 61.45 & $0.000^{* * *}$ \\
Net Interest Margin & 1.99 & 1.88 & 0.21 & 1.84 & 1.15 & $0.000^{* * *}$ \\
Tier 1 Capital Ratio & 14.89 & 10.76 & $0.000^{* * *}$ & 15.03 & 11.15 & $0.000^{* * *}$ \\
& & & & & & \\
Liabilities (over total liabilities & and equity) & & & & & \\
Equity & 7.90 & 6.21 & $0.000^{* * *}$ & 7.69 & 4.08 & $0.000^{* * *}$ \\
Alternative Equity & 1.00 & 0.63 & $0.0198 * *$ & 0.84 & 0.45 & $0.000^{* * *}$ \\
Alternative Debt & 0.75 & 0.54 & $0.000^{* * *}$ & 0.53 & 0.43 & $0.052^{*}$ \\
Subordinated Debt & 1.50 & 1.74 & $0.0247 * *$ & 1.63 & 1.45 & 0.21 \\
Senior Debt & 16.77 & 17.98 & 0.19 & 18.97 & 15.02 & $0.001 * * *$ \\
Customer Deposits & 48.04 & 42.28 & $0.000^{* * *}$ & 44.16 & 30.79 & $0.000^{* * *}$ \\
Bank Deposits & 28.34 & 10.16 & $0.000^{* * *}$ & 29.74 & 10.08 & $0.000^{* * *}$ \\
Repos and Cash Collateral & 6.67 & 6.85 & 0.86 & 7.88 & 8.06 & 0.89 \\
Other Deposits & 8.70 & 6.41 & $0.007 * * *$ & 10.07 & 6.66 & $0.000^{* * *}$
\end{tabular}

Table 1: Comparison of subsidiary banks to parent banks (2006-2014)

Risk and funding characteristics are compared with parent banks for (i) Cross-Border subsidiaries (ii) domestic subsidiaries over the period 2006-2014. Mean values are shown in each case. The equality of means test for samples with unequal variance is used to test the null hypothesis that the difference in sample means is equal to zero. p-values are given in each case and $* * *, * *, *$ indicate that the null hypothesis is rejected at a $1 \%, 5 \%$ and $10 \%$ level respectively. Loan loss provisions and loan loss reserves are given relative to gross loans, liquid assets is relative to deposits and short-term funding, and other deposits includes all alternative short term borrowings. 


\begin{tabular}{|c|c|c|c|c|c|c|}
\hline & \multicolumn{3}{|c|}{2008} & \multicolumn{3}{|c|}{2014} \\
\hline & $\begin{array}{c}\text { Domestic } \\
\text { Subsidiary }\end{array}$ & $\begin{array}{c}\text { Cross-Border } \\
\text { Subsidiary }\end{array}$ & $\begin{array}{l}\text { Equality } \\
\text { of Means }\end{array}$ & $\begin{array}{c}\text { Domestic } \\
\text { Subsidiary }\end{array}$ & $\begin{array}{c}\text { Cross-Border } \\
\text { Subsidiary }\end{array}$ & $\begin{array}{l}\text { Equality } \\
\text { of Means }\end{array}$ \\
\hline Z-Score & 24.92 & 40.75 & $0.000 * * *$ & 24.56 & 68.09 & $0.000 * * *$ \\
\hline Net Loans to Total Assets & 59.98 & 54.25 & $0.000 * * *$ & 56.49 & 52.32 & $0.010 * *$ \\
\hline Loan Loss Reserves & 2.49 & 2.91 & $0.025 * *$ & 5.29 & 4.85 & 0.31 \\
\hline Loan Loss Provisions & 1.30 & 0.89 & 0.11 & 1.46 & 0.79 & 0.32 \\
\hline Liquid Assets & 43.99 & 57.72 & $0.003 * * *$ & 59.07 & 51.07 & 0.18 \\
\hline Net Interest Margin & 1.89 & 1.94 & 0.82 & 1.38 & 1.30 & 0.59 \\
\hline Tier 1 Capital Ratio & 10.65 & 9.75 & 0.33 & 15.46 & 18.13 & $0.087 *$ \\
\hline \multicolumn{7}{|c|}{ Liabilities (over total liabilities and equity) } \\
\hline Equity & 8.09 & 9.30 & $0.0474 * *$ & 8.65 & 9.29 & 0.28 \\
\hline Subordinated Debt & 2.35 & 1.94 & 0.39 & 1.68 & 1.94 & 0.45 \\
\hline Senior Debt & 17.25 & 15.18 & 0.25 & 8.43 & 9.52 & 0.47 \\
\hline Customer Deposits & 45.53 & 41.85 & $0.012 * *$ & 47.26 & 51.19 & $0.008 * * *$ \\
\hline Bank Deposits & 31.89 & 35.87 & $0.006 * * *$ & 31.85 & 25.29 & $0.000 * * *$ \\
\hline Other Deposits & 10.91 & 8.21 & 0.44 & 4.64 & 9.17 & $0.006 * * *$ \\
\hline
\end{tabular}

Table 2: Comparison of matched cross-border and domestic subsidiary banks

Risk and funding characteristics are compared for a matched sample of domestic and overseas subsidiaries for the years 2008 and 2014. In each case the subsidiaries are matched due to a common parent bank, and mean values are shown in each case. The equality of means test for samples with unequal variance is used to test the null hypothesis that the difference in sample means is equal to zero. p-values are given in each case and $* * *, * * *$ indicate that the null hypothesis is rejected at a $1 \%, 5 \%$ and $10 \%$ level respectively. Loan loss provisions and loan loss reserves are given relative to gross loans, liquid assets is relative to deposits and short-term funding, and other deposits includes all alternative short term borrowings. 
(i) Systemically Important Subsidiaries (Assets Greater than $€ 30$ Billion)

\begin{tabular}{lcccccccc}
\hline & \multicolumn{2}{c}{ Cross-Border 2014 } & \multicolumn{2}{c}{ Cross-Border 2008 } & \multicolumn{2}{c}{ Domestic 2014 } & \multicolumn{2}{c}{ Domestic 2008 } \\
Writedown & Senior Debt & Deposits & Senior Debt & Deposits & Senior Debt & Deposits & Senior Debt & Deposits \\
\hline $5 \%$ & $8 \%$ & $0 \%$ & $23 \%$ & $0 \%$ & $22 \%$ & $0 \%$ & $23 \%$ & $0 \%$ \\
$10 \%$ & $53 \%$ & $0 \%$ & $60 \%$ & $0 \%$ & $74 \%$ & $0 \%$ & $55 \%$ & $0 \%$ \\
$20 \%$ & $100 \%$ & $8 \%$ & $100 \%$ & $8 \%$ & $100 \%$ & $13 \%$ & $100 \%$ & $5 \%$
\end{tabular}

(ii) Non-Systemically Important Subsidiaries (Assets Less than €30 Billion)

\begin{tabular}{lcccccccc}
\hline & \multicolumn{2}{c}{ Cross-Border 2014 } & \multicolumn{2}{c}{ Cross-Border 2008 } & \multicolumn{2}{c}{ Domestic 2014 } & \multicolumn{2}{c}{ Domestic 2008 } \\
Writedown & Senior Debt & Deposits & Senior Debt & Deposits & Senior Debt & Deposits & Senior Debt & Deposits \\
\hline $5 \%$ & $0 \%$ & $0 \%$ & $9 \%$ & $0 \%$ & $11 \%$ & $0 \%$ & $12 \%$ & $0 \%$ \\
$10 \%$ & $38 \%$ & $0 \%$ & $51 \%$ & $0 \%$ & $55 \%$ & $0 \%$ & $34 \%$ & $0 \%$ \\
$20 \%$ & $100 \%$ & $8 \%$ & $100 \%$ & $6 \%$ & $100 \%$ & $8 \%$ & $78 \%$ & $0 \%$
\end{tabular}

Table 3: Bail-In Analysis for Differing Bank Writedowns

The level of 'bail-in' required of senior-debt and depositors to cover losses of 5\%,10\% and $20 \%$ of total assets are examined for subsidiary banks in 2008 and 2014. Banks are split into systemic and nonsystemically important subsidiaries. Cross-border subsidiaries are those where the parent bank and subsidiary are located in different countries. Domestic subsidiaries are located in the same country as the parent bank. Banks are from the 28 member states of the EU. 


\section{Appendices}

A. Country Breakdown

\begin{tabular}{|c|c|c|c|}
\hline & $\begin{array}{c}\text { Non-Domestic } \\
\text { Subsidiaries }\end{array}$ & $\begin{array}{c}\text { Domestic } \\
\text { Subsidiaries }\end{array}$ & Parent Banks \\
\hline Austria & 3 & 10 & 5 \\
\hline Belgium & 6 & 2 & 4 \\
\hline Bulgaria & 8 & - & - \\
\hline Croatia & 6 & - & - \\
\hline Cyprus & 3 & - & - \\
\hline Czech Republic & 10 & - & - \\
\hline Denmark & 2 & 4 & 3 \\
\hline Estonia & 2 & - & - \\
\hline Finland & 2 & 5 & 2 \\
\hline France & 7 & 108 & 8 \\
\hline Germany & 22 & 29 & 10 \\
\hline Great Britain & 26 & 39 & 9 \\
\hline Hungary & 8 & 2 & 2 \\
\hline Ireland & 13 & 4 & 2 \\
\hline Italy & 14 & 48 & 19 \\
\hline Latvia & 2 & - & - \\
\hline Lithuania & 2 & - & - \\
\hline Luxembourg & 36 & 1 & 2 \\
\hline Malta & 3 & - & - \\
\hline Netherlands & 5 & 6 & 4 \\
\hline Poland & 18 & 1 & 1 \\
\hline Portugal & 7 & 2 & 3 \\
\hline Romania & 8 & - & - \\
\hline Slovakia & 5 & - & - \\
\hline Slovenia & 3 & - & - \\
\hline Spain & 5 & 16 & 8 \\
\hline Sweden & 1 & 8 & 5 \\
\hline Total & 227 & 285 & 87 \\
\hline
\end{tabular}

Table A.1: Country Breakdown by Bank Type

The number of unique banks in the sample by country are listed for Non-domestic subsidiaries, Domestic subsidiaries and Parent banks. 


\section{B. Variable Definitions}

\begin{tabular}{|c|c|}
\hline ble & Definition \\
\hline & (i) Risk Variables \\
\hline Z-score & $\begin{array}{l}\text { Indicates the number of standard deviations that bank profits must fall to result in insolvency } \\
\text { and is given by (ROA + EA)/std(ROA), where ROA is return on assets, EA is the equity to } \\
\text { assets ratio and the standard deviation of ROA is taken over a 3-year rolling window, } \\
\text { (Abedifar et al., 2013). }\end{array}$ \\
\hline Net loans to total assets & $\begin{array}{l}\text { The proportion of total assets accounted for by loans represents credit risk, (Agusman et al., } \\
\text { 2008). }\end{array}$ \\
\hline $\begin{array}{l}\text { Loan loss reserves to gross } \\
\text { loans }\end{array}$ & $\begin{array}{l}\text { Captures management's assessment of the quality of the loan portfolio (credit risk), inclusive } \\
\text { of performing and non-performing loans and accounts for future expected performance } \\
\text { (Agusman } \text { et al., 2008). }\end{array}$ \\
\hline $\begin{array}{l}\text { Loan loss provisions to } \\
\text { gross loans }\end{array}$ & Loan loss provisions represent a bank's loan impairment charges (Goddard et al., 2007). \\
\hline $\begin{array}{l}\text { Liquid assets to deposits } \\
\text { and short-term funding }\end{array}$ & $\begin{array}{l}\text { Liquid assets include trading securities, loans and advances to banks, cash and due from } \\
\text { banks, and reverse repos and cash collateral. These are normalized by short-term liabilities } \\
\text { (Beltratti and Stulz, 2012). }\end{array}$ \\
\hline Net interest margin & $\begin{array}{l}\text { Net interest margin captures the spread between banks borrowing and lending activities } \\
\text { (Abedifar } \text { et al., 2013). }\end{array}$ \\
\hline Equity to total assets & $\begin{array}{l}\text { Total equity includes ordinary share capital and retained earnings and divided by total assets } \\
\text { is a measure of leverage risk (Agusman } \text { et al., 2008). }\end{array}$ \\
\hline $\begin{array}{l}\text { Tier } 1 \text { capital adequacy } \\
\text { ratio }\end{array}$ & $\begin{array}{l}\text { Total equity plus qualifying perpetual preferred stocks, senior perpetual preferred stock, trust } \\
\text { preferred securities, related interest equity of consolidated subsidiaries less goodwill and other } \\
\text { intangible assets divided by reported risk weighted assets (Beltratti and Stulz, 2012). }\end{array}$ \\
\hline \multicolumn{2}{|l|}{ (ii) Funding Variables } \\
\hline Equity & Com \\
\hline Alternative equity & Preference shares and hybrid capital accounted for as equity \\
\hline Alternative debt & Preference shares and hybrid capital accounted for as debt \\
\hline Subordinated debt & $\begin{array}{l}\text { Unsecured debt which ranks below other debt claims in the event of bankruptcy debt } \\
\text { Senior debt (secured and unsecured) maturing after } 1 \text { year }\end{array}$ \\
\hline Customer deposits & Total customer deposits inclusive of current, savings and term deposits \\
\hline Deposits from banks & Deposits and short-term placements from banks \\
\hline $\begin{array}{l}\text { Repos and cash collateral } \\
\text { Other deposits and } \\
\text { short-term borrowings }\end{array}$ & $\begin{array}{l}\text { Securities sold for cash with an agreement to repurchase them at a specified price on a future } \\
\text { date } \\
\text { Any short term funding not included above }\end{array}$ \\
\hline
\end{tabular}

\section{Table A.2: Variable Description}

Description of variables employed to represent banking risk and funding. Data is sourced from Bankscope. 